\title{
Thinking the Work of Craft as City's Identity Case Study: Special Region of Yogyakarta, Indonesia
}

\author{
Alvi Lufiani ${ }^{1 *}$ Setiawan Sabana ${ }^{2}$ Andryanto Rikrik Kumara ${ }^{3}$ Yan Yan Sunarya ${ }^{4}$ \\ 1. Doctoral Study Program of Visual Arts and Design, Faculty of Art and Design, Bandung Institute of \\ Technology \\ 2. Doctoral Study Program of Visual Arts and Design, Faculty of Art and Design, Bandung Institute of \\ Technology \\ 3. Doctoral Study Program of Visual Arts and Design, Faculty of Art and Design, Bandung Institute of \\ Technology \\ 4. Doctoral Study Program of Visual Arts and Design, Faculty of Art and Design, Bandung Institute of \\ Technology
}

\begin{abstract}
Art in public spaces is often associated with fine art, sculptures in particular. The association changes along with the development of visual art, as happens in Yogyakarta, Indonesia. There are innumerable artistic and cultural novelties and happenings in Yogyakarta that it is known as the city of culture. One of the novelties is the utilization of craft work as the art in the city's strategic public spaces. Evidently this change incites various reactions since it never happened before. Craft art was associated with the small, practical, functional, and massproduced objects placed indoor. With this significant change, it can be said that craft has highly developed. Therefore, it becomes an interesting object to study. Evidently craft products can exist in Yogyakarta public spaces and it can be an icon as well as the city identity. This is a qualitative research with interdisciplinary approach. This analysis of the craft in Yogyakarta public spaces is based on the craft, aesthetic, public art, expansion theory, and sociology of art. This paper describes the changes in craft that it occupies Yogyakarta public spaces. The phenomenon of such changes provides a new dimension in enhancing knowledge in the craft domain.
\end{abstract}

Keywords: Craft, Public Art, City, Yogyakarta

DOI: $10.7176 / \mathrm{ADS} / 76-10$

Publication date:September $30^{\text {th }} 2019$

\section{Introduction}

Yogyakarta or also known as Jogja is the capital of one of the provinces in Java, and it is a special region. Yogyakarta once was the capital of Indonesia before Jakarta replaced it. Yogyakarta has a lot of distinct features; therefore, special region title fits it.

There are various titles for Yogyakarta, from the city of students, the city of arts and culture, to, interestingly, the city of crafts. It is called the city of students since there are more than hundred universities in the city, either public or private. Consequently, students from all over the country come there to study. Yogyakarta is known as the city of arts and cultures because there are innumerable famous artists succeed in their struggle there. The city of crafts title is the interesting one because there are a myriad of craft production sites with various materials in Yogyakarta. There are woodcraft, metal craft, leather craft, pottery, and textiles.

It is interesting that there are various central sites for each material in Yogyakarta. Furthermore, there are various genre of crafts, such as traditional craft, contemporary craft, and new craft. The contemporary ones is the spreading one. It is not the kind of craft as people knew it, which is small sized, functional, relatively cheap, mass-produced product placed indoor.

The thriving contemporary craft in Yogyakarta is the expansion of the existing craft's material, size, form, concept, or exhibition aspects. Nowadays, especially in Yogyakarta, craft works are exhibited at the city public places. Not only fine art works, sculptures in particular, craft works occupy public spaces as well. The presence of craft work in Yogyakarta public spaces offers a new possibility that art in public spaces is not restricted to certain genres. It is widely known that the common genre to occupy public spaces around the world is sculpture. The condition is changing, and it is happening in Yogyakarta. There are growing numbers of craft works exhibited in the city public spaces. It is interesting as Yogyakarta is known as the city of crafts. This image is strengthened with the presence of craft works in public spaces. 
Works exhibited in public spaces are known to reflect and represent the identity or the story of the city. Therefore, there are a lot of legendary public space works and tourists curiously come to see it. For examples, there is Hachiko statue in Shibuya, Japan. Hachiko's is a touching story, and the existence of the statue makes it feels real. The tourists will not miss the chance to take a picture or just observe it. The experience confirms their trip and satisfies them. The presence of work of art in public spaces is an important issue. Therefore, the preparation must be carefully and thoroughly planned.

\section{Methodology}

This is a qualitative research with interdisciplinary approach. The data are obtained from interview, visual data gathering, and literature-based research. The visual data are obtained from works in Yogyakarta public spaces from 2000 until 2017, either they are still existing or not. Filed data collection method will be carried out through, beside literature study, interview with resources from the local community and visitors, local public figure, spreading questionnaires, documentation of the public art space, and supporting data will be utilized as much as possible to get valid data.

This research is mainly based on craft, expansion, and aesthetic theory. Furthermore, public spaces theory and sociology of art are applied as well.

\section{Literature Review}

When we talk about the existence of art in public spaces in Indonesia, especially in Yogyakarta, it is inevitable to talk about socio-cultural context of the place. Local government is also an important institution. For, the existence of art in public spaces is influenced by local government policies. Literatures about art in Indonesian public spaces generally talk about mural, graffiti, or sculptures. There is no literature about craft works. Therefore, this literature review will cover art in Yogyakarta public spaces in general.

Art in public spaces has been a phenomenon in Indonesia. It sprung up in the late 1990s and spread in the 2000s. In its early stages the authoritarian capitalistic New Order regime was still ruling. In the late 1990s urban art was still a small, sporadic, limited movement, and only a guerrilla activity (Barry, 2008).

Basically, urban art is an art which exhibited at remote public spaces. It is a communication medium and it criticizes society as well. Meanwhile, craft art in public spaces is what we called street furniture. Recently, Malioboro Street, a commerce and shopping central in Yogyakarta, was announced as a car-free zone. The pedestrian zone in the area will be renovated. Yogyakarta-themed street furniture will be placed there.

Ulrich Blanche wrote about street furniture in the developed countries. He said that street furniture have a lot of potentials to be studied and developed, that it could be an interesting icon of the city. The icon could be a representation of various cultural values, heritages, histories, or a reflection of the community situation, in this case the residents of Yogyakarta (2015).

\section{Result and Discussion}

As the city of culture as well as the second travel destination in Indonesia after Bali, it is no wonder that Yogyakarta keeps on improving itself to maintain its identity. The placement of work of art in central sites in Yogyakarta has proved to attract local and foreign tourist. It is worth to note that Yogyakarta also known with its established and lasting craft tradition. It has been supported by the Kingdom of Yogyakarta also known as Kraton (Palace) Yogyakarta, one of its Javanese cultural patrons. Kraton distinguished craft tradition in Yogyakarta into great tradition and little tradition. Great tradition sprung from the court craftmans called Empu who lived in Kraton and created masterpiece. In the other hand, little tradition was developed by the masses in the rural area and dominated by practical everyday crafts, such as household items, kitchenware, etc.

Craft work in Yogyakarta public spaces sprung from the development and expansion of these established traditions. The works are well appreciated by general public and experts. While some people admire it, some others condemn it. It is reasonable since initially art in public spaces dominated by sculptures. The presence of craft work in public spaces incited various responses.

In fact, the presence of craft work in Yogyakarta public spaces can bring new and fresh atmosphere to the existing outdoor scenery. Not only is it different, crafty sides of the works represent the identity of Yogyakarta as the city of crafts. Yogyakarta is different from other major cities in Indonesia that have established visual art tradition.

The city's visual art tradition arose from the development of craftsmanship in the city. Then, the development of any visual art around the world affected the crafts. After all, globalization affects craft. Craft, which initially 
known as domestic art, meaning its common place is indoor, has expanded and occupied outdoor, especially public spaces. It is indeed a great breakthrough and should be appreciated.

Craft works like Kuda Egrang and Petangguh by Timbul Raharjo can convey different perspectives. Their initial presences in Yogyakarta public spaces incite various responses. It is understandable since society, either general public or visual art communities, has not accustomed to it. They accustomed to sculpture in public spaces. Despite of that, Raharjo works have a lot dimensions, from the craftsmanship as the distinct characteristic of craft, to the substantial handicraft touch and the intimacy to the materials. Despite their iron and aluminum materials, these works are not felt inhuman or cold since there are abundant manual handicrafts. The utilization of thousands aluminum pipes reinforce that impression. Waste pipes arranged into horse and lion figure. Raharjo's choice of horse figure relates to his background. Raharjo, known as a multitalented person, came from a traditional potter family who lives in pottery central Kasongan, Yogyakarta.

Initially Kasongan was a modest village in South Yogyakarta that produced various potteries, from cooking ware to house decoration with a simple, basic, and rather boring design due to its uniformity, either in size, color, shape, or decoration. It continued for a long time that the villagers had a very modest income and rather impoverished.

And then finally came the great artist Sapto Hoedoyo. He made the clay into a great art that shocked and invigorated Kasongan residents at the same time. Shocking since they did not expect that clay had a lot of potentials as other materials and it was something that never happened before. Invigorating since, along with their visual aspect and artistic merits, the works still had the practical and functional values, the distinct features of crafts.

The major change was in the visual aspect. The products became novel and more appealing. It definitely affected the sales of Kasongan potteries. Foreign buyers came along with domestic buyers. Those buyers gave new, contemporary, and up to date ideas to the craftsmen and businessmen in Kasongan that they produce even more varied products. This also improved craftsmen skill as new design demanded certain craftsmanship. Therefore, there were so many advantages for the Kasongan craftsmen after those changes.

Getting back to the craft in Yogyakarta public spaces, these are the skills they applied to the work in Yogyakarta public spaces. As Timbul Raharjo said, there are many things to consider when an artist wants to bring a craft work that has been placed indoor, to outdoor since the work will be visible and seen by people from various backgrounds (Raharjo, 2016). Sowada said that requirements of public art are: the works must connect public and communities, gain attention for the economic improvement, connect the artists and public, and improve public appreciation of art (2012). Not to mention that the work must be safe and durable for a long period of time. Hence, actually art in public spaces embodies myriad of meaning and complex process.

Raharjo's Kuda Egrang indirectly educates general public that craft is not stagnant. As is the case with others visual art sectors, craft is ever-changing, responding to contemporary situation (Adamson, 2010:4).

Kuda Egrang also represents some aspect of Javanese culture. This culture sees horse as an important animal and inseparable aspect of the true Javanese men. A man is refined man when he has wisma, wanita, turangga, kukilo, and curigo. In a general translation, those mean house, wife, horse, pet, and keris or weapon. I want to discuss further about turangga or horse in the context of Kuda Egrang.

Turangga generally means horse. However, for a deeper understanding of it, horse must be studied from various perspectives. Horse is a strong, fast, and stout animal. People use those features to make activities in everyday live more powerful, faster, and easier. Horse always associated with excellent qualities. Horse speaks with its functions, not with its mouth. Those functions surpass linguistic, cultural, and religious boundaries. Its language is so universally understood that it can be said that Kuda Egrang can reflect not only craftsmanship visually and artistically, but also its contextual and cultural aspects too. This work is not only a reminder, but also a representation of culture, in this case Javanese culture, so people, especially youths, could understand it in an interesting way. As Kus Indarto said, a work of art in public is not ahistorical therefore it has no distance with its immediate audience, in this case local residents, that it has visual and emotional intimacies (2016). This image below is the picture of Timbul Raharjo's Kuda Egrang in a strategic area in Yogyakarta public spaces. 


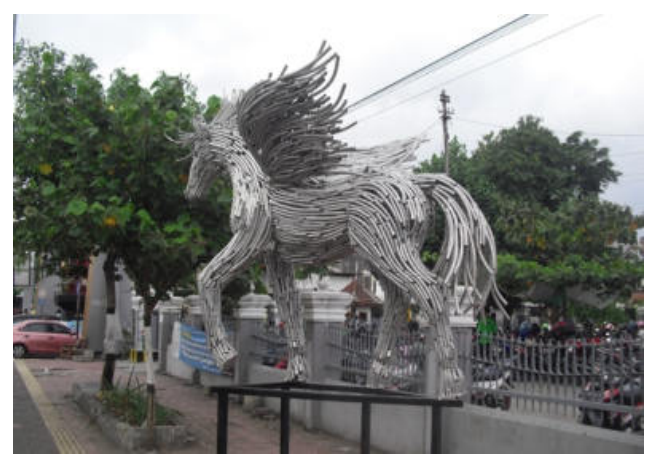

Figure 1. Kuda Egrang created by Timbul Raharjo, 2015. Located in front of main Train Station in Yogyakarta, Indonesia.

Aside from Kuda Egrang, Becakku Tak Berhenti Lama by Nasirun is another work presence in Yogyakarta public spaces. Interestingly, Nasirun is a contemporary abstract painter, but he has intimacy with and love for craft. He is knowledgeable about craft as well since he studied Batik and wood carving when he was in vocational school. Nasirun's passion about Batik is not only because of its beauty but also of the philosophy value. As Dharsono mention that batik is a reflection of glorification culture for its served as guidance or philosophy for life that illustrated on especially classical batik motif (2019). Moreover, he has loved wayang or traditional puppet leather deeply since young. And this affected his arts.

Becakku Tak Berhenti Lama is one of the sophisticated public space works due to its cultural, craftsmanship, and philosophical meaning. In other words, it has a lot of visual and contextual meanings. As Nasirun said, he created it to satirize the elites who approach the impoverished (read: tukang becak or the pedicab driver) in droves only when they need their votes. After the election was over, they return to their indifference again. As usual, the existence of the impoverished as represented by pedicab driver is forgotten again and considered as non-existent.

Visually, it can be said that Becakku Tak Berhenti Lama is a replica of a pedicab since it certainly made as identical as real pedicab. The differences, though, are this work incorporates a lot of craft features, such as traditional ornaments on the seat, backrest, and walls, as with hood decorations and carving on the body. It shows a terrific and detailed craftsmanship, the inseparable characteristics of a craft work. The picture below is Nasirun's Becakku Tak Berhenti Lama.

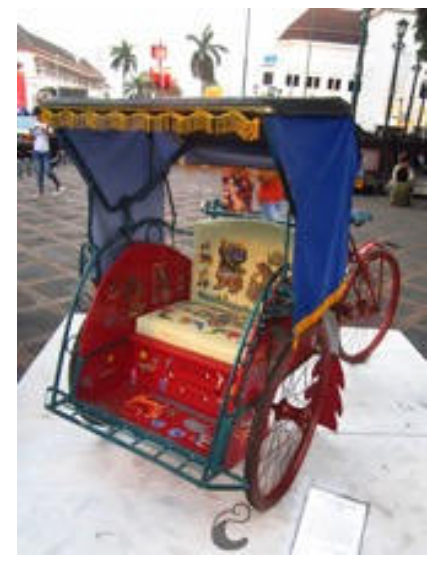

Figure 2. Becakku Tak Berhenti Lama by Nasirun. One of craftworks in public art in the city of Yogyakarta

Historically, this work obviously has a deep intimacy with Yogyakarta. For, Yogyakarta is one of the cities that still sees pedicab as a mode of transportation, unlike some major cities in Indonesia, such as Jakarta, Surabaya, or Bandung that restricted it. On the contrary, in Yogyakarta pedicab still has a crucial role and used as one of the 
attractions for foreign tourists. Pedicab presences not only in the rural and outskirt area, but also occupies strategic area, such as Malioboro. Interestingly, it is not only the nostalgia-driven middle aged people who ride pedicab, but also youths and foreign tourists who want to experience the city with breeze. Therefore, it can be said that the work succeed to become one of the Yogyakarta icons with a deep meanings.

\section{Conclusion}

Based on this study, it can be said that craft, as a part of visual arts, and essentially the roots of visual arts in Indonesia, is highly developed. Craft is not only placed in private and domestic spaces, but also occupies public spaces in Yogyakarta. The craft work in those public spaces could be a representation of Yogyakarta city identity that has an established and very intimate craft tradition with its residents. Those outdoor craft works can be an educational medium about craft and Yogyakarta history, culture, and philosophy. Yogyakarta as the city of culture should provide a wide space for meaningful, sophisticated, and timeless public arts that relate to its residents. In the other hand, public craft art is expected to be well-crafted visually and contextually, so it has meaningful and enduring existence. The presence of craft art in public spaces improves not only the city aesthetics, but also grows pride of the city in the heart of the residents. Therefore, the residents will always attempt to preserve the works and make them as a part of their identity and the city they proud of.

\section{References}

Adamson, G (2010). The Craft Reader. New York: Berg Publisher.

Barry, S (2008). Jalan Seni Jalanan Yogyakarta. Yogyakarta : Penerbit Studium

Banche, U. (2015): Street Art and Related Terms-discussion and Working Definition, Street Art and Urban Creativity Scientific Journal; Methodologies for Research, 32-39.

Dharsono, (2019): The Dynamics of Surakarta Batik: The Development of Batik through Conservation by Revitalization and Reinterpretation in the Development Dynamics of Surakarta Batik. Journal of Art and Design Studies. DOI.10.7176/ADS. Vol.74, p.29-39.

Indarto, K (2016): Mengidealkan Public Art. Yogyakarta : Taman Budaya Yogyakarta

Risatti, H. (2007): A Theory of Craft. Chapel Hill: The University of North Carolina Press,

Sowada, K.J (2012) : P.A.I.N.T : A Case Study in Engaging The Community Through Public Art. Electronic Theses and Dissertation. Paper 1361. Https://doi.org/10.18297/etd.1361 